\title{
CONTEMPORARY ROMANIAN MIGRATIONS TO SERBIA: STAGES, ACTORS, REASONS
}

\author{
ANNEMARIE Sorescu-Marinkovic
}

\begin{abstract}
Contemporary Romanian migrations to Serbia: stages, actors, reasons.
This paper aims at offering insight into the contemporary migration of Romanians towards Serbia, starting with the interwar period, continuing with the communist rule and focusing on the period after the fall of the Romanian communist regime, in 1989. What this study does is delimit the stages of the Romanian migration to Serbia, identify the social categories taking part in these migratory processes, the preferred regions for settling in Serbia, as well as the reasons behind people's decision to leave the country. I also show how the Romanian emigrants relate to the Romanian autochthonous communities in Serbia (the Vlachs of Eastern Serbia and the Romanians o Vojvodina), in which they usually settle.

After presenting the theoretical background relating to ethnic migrations, I introduce a new theoretical concept, reverse ethnic migration, which best fits the situation of contemporary Romanian migrants to Serbia. These migrations take place from a majority (Romanians in Romania) towards a national minority (Romanians or Vlachs in Serbia), thus in an „opposite” direction. The migrations are not state supported and they are individual in most of the cases. I argue that the interwar migrations were state planned, being the result of the Yugoslav-Romanian School Convention from 1933; those taking place during communism were triggered, in many instances, by political reasons; while the post-communist migration was labour oriented.
\end{abstract}

Author: Annemarie Sorescu-Marinkovic, Institute for Balkan Studies, Serbian Academy of Sciences and Arts, Knez Mihailova 35/IV, 11000 Belgrade, annelia22@yahoo.com

Keywords: migration, ethnic migration, Romanians, Vlachs, Eastern Serbia, Vojvodina

Balcanica Posnaniensia. Acta et studia, XXIII, Poznań 2016, Wydawnictwo Instytutu Historii UAM, pp. 151165, ISBN 978-83-65663-26-9, ISSN 0239-4278. English text with a summary in English.

doi.org/10.14746/bp.2016.23.10

\section{INTRODUCTION}

This paper stems from a larger research carried out between 2015 and 2016 with the aim of mapping down the Romanian diaspora on the territory of neighboring Serbia, formed in the last 25 years. After finishing the research and publishing the preliminary results ${ }^{1}$, the need to take a better look at the migratory processes that were

${ }^{1}$ One of the results of this project is: A. Sorescu-Marinković, Foggy diaspora: Romanian Women in Eastern Serbia, „Studia UBB Sociologia”, 2016, vol. 61, no 1, p. 37-57. In this study I take a look at the 
characteristic to this region not only after the fall of the communist regime, but also during the communist rule, became evident. The formation of the Romanian diaspora cannot be completely understood if we consider it an exclusively post-communist phenomenon. In the contemporary period, the movements of the Romanian population from one side of the Danube to the other and from one state to the other have had an almost permanent character, even if their intensity and dynamics were strongly influenced by the political situation.

I decided to analyze these movements of population starting with the interwar period, when the first Romanian citizens are sent to the newly formed Yugoslavia, after setting the border between the two neighboring states, in 1918, to teach Romanian in the Romanian schools in Vojvodina. During the communist period, migrations from Romania were strictly controlled by the state, but there are also cases of fugitives who settled in Yugoslavia, their migration being triggered by political reasons. After the fall of the Romanian communist regime, in December 1989, and the liberalization of international travel, many Romanians arrived in Serbia and some settled there. Generally speaking, the post-communist migration was labour oriented and, in the beginning, had a temporary character, but in time it diversified and became permanent.

These migrations might seem unusual from today's view point, when Romania is a European Union country, while Serbia is not. However, if we take a look at the bigger picture and at the migration patterns of the region throughout its recent history, the perspective might change. Needless to say, with the opening of the labour markets of Western Europe for Romanians, the last ten years saw a drastic decrease of newcomers from Romania to Serbia. Today, Serbia is hardly an attractive destination country and the opposite phenomenon, the migration of Serbs or of ethnic Romanians from Serbia to Romania, might prove a fruitful topic of research.

\section{ETHNIC MIGRATION AND REVERSE ETHNIC MIGRATION}

Even if the concept of ethnicity and its analytical utility have been intensely debated lately ${ }^{2}$, it is a fact that ethnicity has been for more than 50 years a central issue in migration studies. Starting with the first observations of sociologists on the important role of ethnicity in the integration and assimilation of the groups of immigrants in the United States ${ }^{3}$, ethnicity as a lens of getting valuable insight into the processes at stake within immigrant groups and between them and the host societies has been widely used by various migration scholars all through the $20^{\text {th }}$ century. The shifting of the focus from the ethnic to other perspectives, which happened in the beginning of the $21^{\text {th }}$ century, opened up the possibility of new theoretical and empirical approach-

Romanian diaspora from Eastern Serbia, settled there after the fall of the communist regime in Romania, with the consequent opening of the borders.

${ }^{2}$ R. Brubaker, Ethnicity without Groups, Cambridge 2004.

${ }^{3}$ M. Gordon, Assimilation in American Life, New York 1964. 
es. However, migration scholars still maintain that ethnicity continues to be relevant in understanding the context, course, and consequences of international migration ${ }^{4}$.

In today's modern world, stirred up by international migration, which disrupts the national order of things, ethnicity proves to be of utmost importance in cushioning the impact of migration. What has been labeled ethnic migration refers to the intrinsic inclination in modern nation-states to select newcomers in light of their proximity to the particular ancestry and destiny definitions they happen to adhere to ${ }^{5}$. The prevalent assumption was that the closer an immigrant's profile is to that of the native population, the more desirable the newcomer ${ }^{6}$. The politics and policies designed to favor individuals abroad, in the sense of offering them a privileged migratory or citizenship status, on the basis of presumed common origins with the host state's people foster the expectation that ethnic affinity facilitates social and economic integra$t_{i o n}{ }^{7}$. Among the best-known examples of people affected by these ethnic affinity policies are the Aussiedler or ethnic Germans, the members of the Jewish diaspora ${ }^{8}$, but also Latin Americans descended from Italian, Japanese and Spanish emigrants, ethnic Hungarians in Eastern Europe, descendants of the Irish in the Americas, and Estonian-descent West Siberians 9.

As far as the recent ethnic migration of Romanians is concerned, probably the most prominent is the massive (re-)naturalization, in the 2000's, of Moldovan and Ukrainian citizens stripped of their Romanian nationality following the 19401941/1944 Soviet occupation of Bessarabia and Northern Bukovina ${ }^{10}$. Aromanians and Macedo-Romanians in the Balkans were also granted Romanian citizenship and their migration to Romania was supported in the interwar period. An important role in this process of „returning” played the Macedo-Romanian Cultural Society, which was founded in Bucharest in 1879 and was a responsible to grant civil status documents necessary for obtaining Romanian citizenship ${ }^{11}$. The legal category emigrant returnee has been widely applied in Europe (but also worldwide) in the last one hundred years to people who may have never set foot in the state they migrated to, but claimed nationality by virtue of history and familial ties.

In light of these facts, the Romanians who migrate to Serbia and settle mainly in the autochthonous Romanian communities existing there, which today represent na-

${ }^{4}$ I. Culic, R. G. Anghel, Ethnicity in Migration. Romanian Immigrants at Home and Abroad, ,Studia UBB Sociologia", 2012, vol. 57, no 2, p. 4.

${ }^{5}$ C. Joppke, Selecting by Origin. Ethnic Migration in the Liberal State, Cambridge 2005, p. ix.

${ }^{6}$ D. Cook-Martín, A. Viladrich, The Problem with Similarity: Ethnic-Affinity Migrants in Spain, "Journal of Ethnic and Migration Studies", 2009. vol. 35, no 1, p. 152.

${ }^{7}$ Ibidem, p. 151.

${ }^{8}$ C. Joppke, op. cit.

${ }^{9}$ D. Cook-Martín, A. Viladrich, op. cit., p. 152.

${ }^{10}$ C. Iordachi, Politics of citizenship in post-communist Romania: Legal traditions, restitution of nationality and multiple memberships, in: Citizenship Policies in the New Europe, eds. R. Bauböck, B. Perchinig, W. Sievers, Amsterdam 2009, p. 177.

11 More about this in: E. Ţîrcomnicu, Identitate românească sud-dunăreană. Aromânii din Dobrogea: sărbători, obiceiuri, credinţe, cultură şi viaţă comunitară, Bucureşti 2004. 
tional minorities, are not considered returnees, nor are they supported by policies of the Serbian state. However, the ethnic component of this type of migration is obvious. They capitalize on the shared language and are more likely to share linguistic competencies, religion, customs and orientations with natives. We can label this peculiar type of migration reverse ethnic migrations, as they take place from a majority (Romanians in Romania) towards a national minority (Romanians or Vlachs in Serbia), thus in an „opposite” direction, are not state supported and in most of the cases are the result of individual enterprise.

\section{ROMANIANS IN SERBIA: AUTOCHTHONOUS COMMUNITIES AND NEW SETTLERS}

Neighbouring Serbia is inhabited by an important number of Romanian speakers. They belong partly to autochthonous Romanian communities, partly to recently formed ones, by migration from Romania. Recent Romanian settlers have mainly anchored themselves in the already existing Romanian speaking communities, capitalizing on their common language. These new settlers form what has been labeled as near Romanian diaspora or foggy diaspora ${ }^{12}$, as they merged with the „old” Romanians and are an almost invisible minority, hidden within another minority.

The first autochthonous Romanian speaking community are the Romanians of Vojvodina (Serbian Banat). They are officially recognized as a Romanian minority in Serbia and have access to schooling, mass media and religious service in the Romanian language. The last population census of 2011 put forth a number of 29332 Romanians who inhabit around 40 settlements in Central and Southern Vojvodina. Some of these localities are mentioned in medieval archives, while others were established later, in the 18th or beginning of the 19th century, during the Austro-Hungarian colonization of the Banat ${ }^{13}$. They speak more or less archaic variants of the Romanian language, with the Banat-based dialect being the most widespread ${ }^{14}$. The Romanians of Vojvodina do not hesitate to declare their Romanian ethnic identity, have a strong ethnic consciousness and foster close ties to Romania, as many have relatives there.

The other Romanian speaking autochthonous community are the Vlachs of Eastern Serbia. The Vlachs are a mainly rural, traditional and conservative community, ex-

\footnotetext{
12 A. Sorescu-Marinković, Foggy diaspora: Romanian Women in Eastern Serbia, „Studia UBB Sociologia", 2016, vol. 61, no 1, p. 39-41.

${ }^{13}$ More on the history of the Romanians in Vojvodina in: G. Popi, Românii din Banatul Sârbesc, Pancevo 1993; M. Măran, Românii din Voivodina - istorie, demografie, identitate românească în localităţile Voivodinei, Zrenjanin 2009.

${ }^{14}$ More on the language of the Romanians in Vojvodina in: R. Flora, Rumunski banatski govori u svetlu lingvističke geografije, Beograd 1969; B. Sikimić, Romanians in Serbian Banat: Dynamic Epistemology, in: The Multilingual Society Vojvodina. Intersecting Borders, Cultures and Identities, eds. T. Kamusella, M. Nomachi, Sapporo 2014, p. 51-73.
} 
tremely divided, with a double, contextual identity ${ }^{15}$. Its members declare themselves as Romanians, Vlachs or Serbs and accordingly, but not necessarily in an overlapping manner, they declare their mother tongue is Romanian, Vlach or Serbian. According to the last population census, their number is 35330 , but unofficial estimates made by the members of the community put forth much bigger figures, anywhere between 150 000 and 300000 . There is no generally accepted opinion regarding the origin and history of this community. Some authors consider that the Romanian nation formed on both banks of the Danube, others that the Vlachs have migrated from Romania to the south of Danube sporadically, in different periods, starting with the 17th century, in search of free land and trying to escape the oppression of the rulers ${ }^{16}$. If Romania does not hesitate in considering the Vlachs of Eastern Serbia Romanians and talks of only one Romanian minority in the neighboring country, Serbia is still operating a clear-cut division between the Romanians of Vojvodina and the Vlachs.

Romanian linguists consider that Vlachs speak an archaic, dialectal variant of Romanian, uninfluenced by the evolutions that Romanian has been undergoing in the last centuries, including the creation of a standard language ${ }^{17}$. However, the Vlach language planning actors, language enthusiasts and ideologues affiliated to the independentist, pro-Vlach faction within the Vlach community, claim that Vlach is a language in its own right ${ }^{18}$. The long-standing contact with Serbian and the numerous loans from Serbian grant this contact variety a special lexical profile, which is why some speakers of the Romanian standard language, with little knowledge of its dialects, might find it hard to understand Vlach ${ }^{19}$. Until recently, the Vlachs have not been granted any minority rights regarding the use of their mother tongue, but things are rapidly changing: in 2014 the first Vlach language textbook was printed and Vlach

15 More about the double identity of the Vlachs in: D. Dimitrijevic-Rufu, Rites de passage, identité ethnique, identité nationale - Le cas d'une communauté roumaine de Serbie, „Terrain”, 1994, no. 22, p. 119-134.

${ }^{16}$ For an overview of the research on the origin of the Vlachs, see: A. Sorescu-Marinković, Românii din Timoc astăzi. Fiinţe mitologice, Cluj-Napoca 2012.

17 The region of Eastern Serbia inhabited by a Romanian speaking population has only sporadically been visited by Romanian researchers. One of the most notable recent attempts is the creation of a linguistic atlas of this region, meant to place the Vlach vernaculars in the wider context of Romanian dialects: P. Neiescu, E. Beltechi, N. Mocanu, Atlas Lingvistic al Regiunii Valea Timocului. Contribuţii la atlasul lingvistic al graiurilor româneşti dintre Morava, Dunăre şi Timoc, Reşiţa 2006.

18 Their ideology is mainly displayed in two programmatic materials. The first is the preface of Grammar of the Vlach language (N. Jovanović, Gramatika vlaškog jezika, Negotin 2013), signed by Dragan Andrejević, art historian, which bears the title The status of the Vlach language and its dialects (Položaj vlaškog jezika i dijalekti). The second is the manifesto Language and alphabet as the most important features of the national identity of the Vlachs (Jezik i pismo kao najbitnija obeležja nacionalnog identiteta Vlaha) - (http://www.nacionalnisavetvlaha.rs/jezikipismo.html [accessed: December 15, 2015 ].

${ }^{19}$ For more details on the gap between the Romanian standard language and the Vlach speeches, as well as on the attempts of standardization of the Vlach vernaculars, see: M. Huţanu, A. SorescuMarinković, „For us, it's not a matter of research, but a matter of life”: language ideologies in the standardization of Vlach in Serbia, paper presented at the conference Communication in the "Country of Babel”. Language Ideological Debates on Contact Varieties, 11th and 12th November 2015, University of Bern (in print). 
was introduced as an optional object in primary schools, while in September 2015 the Vlach National Council adopted the decision of standardization of the Vlach language $^{20}$.

When talking about Romanian autochthonous communities in Serbia, we must also mention the Bayash or Rudari, a former itinerant community which started migrating to Yugoslavia mainly after the abolition of Gypsy slavery in Romania, at the middle of the 19th century. They live dispersed throughout Serbia, and the Balkans, their mother tongue is Romanian, but they are considered the Roma by the surrounding populations, in light of their semi-nomadic way of life (which they have kept until the middle of the last century), mentality and physical characteristics. They do not speak Romany, but their membership in the Romanian nation is intensely contest$\mathrm{ed}^{21}$.

Apart from these Romanian indigenous communities, there are also many Romanians settled in Serbia in the last decades. The categories of people or actors taking part in these migrations, and their reasons have been most diverse. The contacts between Romania and Serbia in terms of population exchange have not ceased throughout the centuries. The regions with Romanian speaking populations in Serbia have served as an anchor for the Romanians moving here, in the same way in which the areas with Serbian-speaking populations acted as an anchor for the Serbs going to Romania. Family ties across the state borders persisted and represented one reason for migrating in any historical circumstances. Labour migrations and political migrations were also well represented in different time periods. Even during the last years of the Romanian communist rule, when the state borders were firmly closed and strictly guarded, illegal movements from one side to the other (mainly from Romania to Yugoslavia) happened frequently. These illicit movements were more common at the border with Vojvodina, due to the land formation, while in Eastern Serbia, where Danube is state border, they were much rarer, as it was more difficult to cross from one side to the other.

\section{CONTEMPORARY ROMANIAN MIGRATIONS TO SERBIA}

In what follows I will offer an overview of the recent migrations of Romanians to Serbia, focusing of the province of Vojvodina and on Eastern Serbia, towards which the bulk of these migrations was directed. I will identify the main stages of migration, the actors taking part in them, as well as the reasons which influenced their decision. Whenever possible and needed from the point of view of argumentation, I will

${ }^{20}$ More on the recent, contested standardization of the Vlach language in: M. Huţanu, A. SorescuMarinković, Graiul vlah în şcolile din Serbia răsăriteană: provocări şi perspective, „Philologica Jassyensia", 2015, vol. 22, no 2, p. 201-211.

${ }^{21}$ For a thorough overview of the Bayash in the Balkans, see: B. Sikimić (ed.), Banjaši na Balkanu. Identitet etničke zajednice, Beograd 2005. 
also point to the reverse process, that of the ethnic Romanians from Serbia moving to Romania. Apart from these two centers which have attracted the Romanian speaking population throughout the centuries ${ }^{22}$, there are also a few other regions where the groups of Romanian citizens have settled, such as the town of Pančevo or the city of Belgrade.

\section{VOJVODINA}

The province of Vojvodina has a long tradition of intense contacts and movements of population from one part of the border to another. If we consider only the recent Romanian migration to Vojvodina, we can identify the three main stages, as follows:

1) The interwar period

At the end of World War I, the Banat was divided between Yugoslavia (the Kingdom of Serbs, Croats and Slovenes, at that time) and Romania. Following this decision, most of the Romanian teachers from Vojvodina, the Serbian part of Banat, moved to Romania $^{23}$. During the 1920 s and 1930s, the Yugoslav and Romanian state tried to find a solution to the education of minorities on both sides of the border. The result of this intense diplomatic activity was the Yugoslav-Romanian School Convention, which was signed in $1933^{24}$. The convention facilitated education in Romanian in Vojvodina and in Serbo-Croatian in the Romanian Banat. On the basis of this convention, Romanian teachers and professors from Romania started arriving, with their families, to Yugoslavia, in 1935. At the end of 1936, there were already 47 teachers, Romanian citizens, in the Romanian schools of Vojvodina ${ }^{25}$. These contractual teachers, the term under which they are generally known, came and functioned in Vojvodina between 1935 and 1948. Many of them remained here for good, started families, gave up the Romanian citizenship and took up the Yugoslav one. Others return to Romania, either because of personal reasons or because they were suspected by the Yugoslav authorities of encouraging nationalism in the rural Romanian communities of Vojvodina ${ }^{26}$.

\footnotetext{
${ }^{22}$ It is beyond the scope of this paper to talk about the history of the Romanian and Vlach communities in Serbia. For details about the history of the Vlachs in Serbia, see: C. Constante, Românii din valea Timocului ş̧i a Moravei, Bucureşti 1929, and C. Constante, A. Golopenţia, Românii din Timoc, Bucureşti 1943, vol. 1-3. About the Romanians in Vojvodina see: G. Popi, Românii din Banatul Sârbesc, Pančevo 1993, and M. Măran, Românii din Voivodina - istorie, demografie, identitate românească în localităţile Voivodinei, Zrenjanin 2009.

${ }^{23}$ G. Popi, Rumuni u jugoslovenskom Banatu između dva rata: 1918-1941, Novi Sad 1976, p. 29.

${ }^{24}$ Ibidem, p. 302.

${ }^{25}$ M. Măran, Românii din Banatul sârbesc în anii interbelici (1918-1941), Cluj-Napoca 2012, p. 105.

${ }^{26}$ G. Popi, Rumuni u jugoslovenskom Banatu između dva rata: 1918-1941, Novi Sad 1976, p. 112.
} 
At the beginning of January 1945, towards the end of World War II, many Romanian ethnics from Vojvodina who refused to enroll in the Yugoslav army were persecuted and fled to Romania. Many were accompanied by their families. By April 1945, 1187 the Yugoslav citizens of the Romanian origin escaped from Vojvodina and settled in the Romanian Banat ${ }^{27}$.

2) The communist period

After a period in which the political relations between Romania and Yugoslavia were frozen, (starting with 1948) and the Serbian ethnics from the Romanian Banat fled to Serbia, being accused of „Titoism" 28 , the political relations intensified again at the beginning of the 1970s. Thus, many Romanian students from Vojvodina started studying at the universities in Romania, mostly in Bucharest and Cluj-Napoca. Some of them came home, after graduation, with spouses whom they met in colleges and were Romanian citizens. In order to marry a foreign citizen in Ceauşescu's Romania, one needed a special approval from the Communist Party, thus getting a passport and moving to Yugoslavia was a difficult process, which could last from a few months to a few years. After settling there, the Romanian citizens were forced to give up their Romanian citizenship in order to take on the Yugoslav one. This wave of the Romanian citizens is much more diverse than the first one in the 1930s, as far as the occupations of the Romanian immigrants are concerned, nevertheless the immigrants were mainly formed of intellectuals.

Apart from that, one must mention that the border region with Yugoslavia had a special regime during the last years of the communist rule: people inhabiting the settlements in the vicinity of the state border had the so-called small-scale trade permits (legitimaţii de mic trafic), which allowed them to pass the border for one-day trips to the markets in Yugoslavia. This was happening in a period when the Romanian authorities were exercising very restrictive exit policies, severely limiting the ability of citizens to travel internationally. Passports were held by the police, and a prior approval from the authorities was required in order to obtain the travel document. Many people from the West and South-West of Romania were engaged in the shuttle trade, but also in various kinds of migration: circular migration, return migration, temporary or permanent migration ${ }^{29}$.

27 E. Mioc, Comunismul în Banat (1944-1965). Dinamica structurilor de putere în Timişoara şi zonele adiacente, vol. II, Timişoara 2010, p. 124.

${ }^{28}$ This period started with 1948, when the Cominform Resolution was passed This resolution accused the Communist Party of Yugoslavia of exhibiting an anti-Soviet attitude, which led to the expulsion of Yugoslavia from Cominform. After this date, Yugoslavia fell outside of the Soviet sphere of influence and its independence from the soviet line, called Titoism, was fiercely criticized by communist Romania. Serbian ethnics from Romania accused of being "Titoists" and of collaboration with Yugoslav communist were persecuted. More on this topic in: I. Nistor, „Procesul titoismului” în România (1950). Documente, Iaşi 2015.

${ }^{29}$ More on the migration of Romanians in the 1980s in: A. Sorescu-Marinković, Romanian female migration to northeast Serbia, in: Migration and Identity: Historical, Cultural and Linguistic Dimensions of Mobility in the Balkans, ed. P. Hristov, Sofia 2012, p. 223. On the other hand, sociologists argue against 
3) The post-communist period

Immediately after the fall of the Romanian communist regime, in December 1989, passport administration and international travel were liberalized. In 1990 only, almost 100000 Romanians moved abroad. This massive emigration was both the result of the relaxation of restrictions regarding international travel and of the turbulent economic and political environment in the country. At the beginning of the 1990s, young, highly qualified emigrants obtained long-term, legal residence in various European countries, the USA and Canada. Thereafter, more and more unskilled or poorly qualified persons from rural areas began seeking migratory arrangements. Talking about the exodus that has been associated with Romania since the 1990s, Ruxandra Trandafoiu considers that it is the cumulative effect of a national psychosis induced by half a century of communism and dictatorship, followed by a lengthy and traumatic transition process $^{30}$. The province of Vojvodina, being so close to Romania, also became host to many Romanian citizens who, before they headed to Western Europe, preferred to try their luck in the wealthy households of Vojvodina Romanians. Some of them stayed here for good, others - only for a few months or years. In the 2000s, several hundred Romanians started small businesses in this region. In the same time, more and more Romanian ethnics from Vojvodina received grants from the Romanian state and went studying at the universities in Timişoara, Bucharest, Cluj-Napoca or Craiova. Many of them chose to stay in Romania, unlike a few decades ago, due to better employment opportunities and higher salaries.

One should also notice that in Vojvodina it is difficult to make a clear distinction between the autochthonous Romanian population and the Romanian citizens, as kinship and social ties between the two groups have persisted throughout the years and individuals have been permanently moving from one country to the other.

\section{EASTERN SERBIA}

Eastern Serbia is another region which, during the last few hundreds of years, had an influx of Romanian population coming from North of the Danube. Even if one accepts the idea that Romanians have inhabited this region from the oldest times, it cannot be denied that the economic, historical and political circumstances led to successive migrations, of different amplitudes, from the regions North to those South of the Danube ${ }^{31}$. These migrations explain not only the common linguistic traits, but

\footnotetext{
labeling of Eastern Europeans as migrants and prefer the term free movers, as Eastern European migration was in that period temporary and circular rather than permanent, stimulated mainly by labor requests. In this respect, see: A. Favell, The New Face of East-West Migration in Europe, "Journal of Ethnic and Migration Studies", 2008, vol. 34, no 5, p. 703.

${ }^{30}$ R. Trandafoiu, Diaspora Online. Identity Politics and Romanian Migrants, Oxford 2013, p. 49.

${ }^{31}$ According to Constantin Constante, there are three possible important dates of Romanian migration to Eastern Serbia: 1) in the 14th century, after the Turkish invazion; 2) in the 17th century; 3) in 1838 and 1848 (see C. Constante, Românii din valea Timocului şi a Moravei, Bucureşti 1929). The Romanian
} 
also the almost identical popular culture of the inhabitants on both banks of the river, Romanians and Vlachs.

As the Vlachs have not enjoyed minority rights until several years ago and the „Vlach question" has been a delicate one for contemporary Serbia, which feared the awakening of a Romanian national consciousness in this province bordering on Romania, or the creation of a too large Romanian minority within the confines of Serbia, there is a lack of sources about this ethnic group for the interwar and communist period. The migrations from Romania were not supported or even tolerated officially, as the infusion of Romanian elements in the area was thought not desired and thought to encourage nationalism in the Vlach villages.

\section{1) The communist period}

The Western Romanian frontier, from which $290 \mathrm{~km}$ along the Danube, has been regularly crossed, from 1944 to 1989, illegally, by Romanians trying to escape the suppressive communist regime (frontierişti; , ,borderer crossers”). Between 1980 and 1989, 16000 Romanians tried to cross the border, and 12000 were caught; only in 1988, 400 people were shot on the border between Romania and Yugoslavia ${ }^{32}$. By that time, Romania's western border had become one of the best protected and bloodiest borders of Europe. There are cases of Romanians who escaped the oppressive Ceaussescu regime and, on their way to the free world, decided to stay in Eastern Serbia, but these are very rare.

\section{2) The post-communist period}

After the fall of the Romanian communist regime, a big share of rural population of Oltenia oriented to Yugoslavia, and engaged in multiple types of migration, difficult to register $^{33}$. The suitcase traders or shuttle traders, already visible in the 1980s in many Eastern European countries ${ }^{34}$, started being noticed at the border with Yugoslavia, too. Most of them were practicing a pendulum movement, going abroad and coming back home in the same day ${ }^{35}$. According to my field observation, Romanians arrived here from all the regions of Romania, with a slight preponderance of Moldova. They were mainly women, with primary or secondary education, low or medium skilled workers with no starting capital, who came in search of work in the village bar, as seasonal

\footnotetext{
historian Ştefan Meteş, talking about the migration of Romanians from Transylvania, also claims that the Romanian autochtonous population of Eastern Serbia has been enforced during the 19th century by Transylvanian Romanians who preferred the Turkish rule to the Austro-Hungarian one (see Ş. Meteş, Emigrări româneşti din Transilvania în secolele XIII-XX, Bucureşti 1977, p. 88).

32 J. Steiner, D. Magheţi, Mormintele tac. Relatări de la cea mai sângeroasă graniţă a Europei, Iaşi 2009, p. 13.

${ }^{33}$ D. Sandu, Migraţia transnaţională a românilor din perspectiva unui recensământ comunitar, „Sociologie românească", 2000, vol. 3-4, p. 21.

${ }^{34}$ C. Wallace, D. Stola (eds.), Patterns of Migration in Central Europe, Basingstoke 2001.

${ }^{35}$ D. Diminescu, Exerciţiul dificil al liberei circulaţii: o introducere în istoria migraţiei recente a românilor, in: Sociologia migraţiei: Teorii şi studii de caz româneşti, eds. I. Horváth, R. G. Anghel, Iaşi 2009 , p. 46 .
} 
workers or as unqualified care taking personnel for the old Vlachs who live alone ${ }^{36}$. In time, most of these mainly young women married Vlach men and settled here, forming a relatively big Romanian diaspora, of about 5000 persons $^{37}$.

My research suggests that the Romanian diaspora in Eastern Serbia is not growing any longer. The process of consolidation reached a peak between 1999 and 2001; after this date, the number of Romanian women coming to Serbia drastically decreased. After 2007, when Romania joined the European Union and the Romanians could freely travel and work in most of the EU countries, the favourite destinations changed, Serbia being chosen only rarely. Many children from mixed marriages of Romanians with Vlachs have double citizenship, both Serbian and Romanian. However, for part of the Romanians in Eastern Serbia, this is now only a temporary destination, as some have already moved to Western Europe, and many others intend to do so in the near future ${ }^{38}$.

Nevertheless, the last ten years witnessed many changes in this region. In 2006, the Dacia Ripensis Deanery from Negotin gained autonomy, being now directly subordinated to the Romanian Orthodox Church. After this date, Romanian churches started to be built in Eastern Serbia, with Romanian missionary priests doing the religious service. In 2012, one more Romanian Consulate was opened in Zaječar, after the ones in Belgrade and Vršac, as recognition of the fact that this region is inhabited by Romanian population. In 2014, optional Romanian language classes were introduced for the first time in primary schools of Eastern Serbia. What is seen by some as a re-Romanization of this region must be, however, considered within the frame of the parallel process of consolidation of the Vlach identity, of the introduction of Vlach in schools, of the creation of a grammar for the Vlach language and its transformation into a separate language, different from Romanian. These are two distinct directions of expressing and strengthening the identity of this ethnic group, going on currently, in which the role of the Romanian newcomers is still to be assessed.

\section{THE TOWN OF PANČEVO}

The town of Pančevo, $20 \mathrm{~km}$ away from the capital Belgrade, is home to a community of Gabori Roma, Romanian citizens, coming from Crăciunești, in Târgu Mureş (Transylvania) and speaking Romanian, Hungarian and Romanes. They do not identi-

\footnotetext{
${ }^{36}$ As many Vlach villages are almost deserted, the young generations live and work in Western Europe (more about this in: Schierup Carl-Ulrik, Will they still be dancing? Integration and ethnic transformation among Yugoslav immigrants in Scandinavia, Umeå 1986.

${ }^{37}$ More about the recent Romanian diaspora in Serbia and the migration of Romanian women to this region in: A. Sorescu-Marinković, Romanian female migration to northeast Serbia, in: Migration and Identity: Historical, Cultural and Linguistic Dimensions of Mobility in the Balkans, ed. Petko Hristov, Sofia 2012, p. 217-231; idem, Foggy diaspora: Romanian Women in Eastern Serbia, „Studia UBB Sociologia", 2016, vol. 61, no 1, p. 37-57.

${ }^{38}$ Ibidem, p. 55.
} 
fy with the Romanian nation, unlike most Roma coming from Romania and settled in Western Europe, and take a great pride on their Gabori identity, traditions and group endogamy ${ }^{39}$. They are all members of the Adventist Church, which they also attend in Pančevo. They have come to Serbia starting with 2005, where they are itinerant traders, selling pots, carpets, chainsaws etc ${ }^{40}$. According to the Adventist pastor, their number raises to 200 in spring, when they come from Romania; they still lead a seminomadic life, in that they are commuting seasonally between Romania, where they spend the winter, and Serbia, where they come in the spring, in order to paddle. A very small number stays over winter in Pančevo. Apart from Pančevo, there are also a few Gabori Roma families living in Kikinda, North Serbia.

During the last years, their number has started to fall, as the economic situation in Serbia worsened, and the purchasing power of the Serbs drastically dropped. Thus, the Gabori Roma started probing other markets and slowly switching to Croatia, Albania, Bulgaria or Russia ${ }^{41}$.

\section{THE CITY OF BELGRADE}

According to the last population census, from 2011, there are 1,282 Romanians in the city of Belgrade. However, this is not the real number of Romanian citizens in Belgrade, but also includes the Romanians from the indigenous community in Ovča, which became, from a village in Vojvodina, a suburban settlement of Belgrade. Most of the Romanian citizens living in Belgrade, probably a few hundred, are highly skilled professionals, working for multinational companies and are currently located here, usually for a definite period of time, together with their families. Belgrade, like any other European capital, has been attracting many foreign workers for the last

39 The largest Gabori Roma communities are to be found in Târgu Mureş, but also in other towns of Transylvania, such as Oradea, Cluj-Napoca, Braşov, Arad, Satu Mare or Timişoara. Most of them have Romanian citizenship and live in Romania, but after the fall of the communist regime, several families moved to Hungary and received Hungarian citizenship (P. Berta, Intermediate trade, migration, and the politics of ethnicity. Economic strategies among Romanian Gabor Roma, "Acta Ethnographica Hungarica", 2014, vol. 59, no 1, p. 43-34.

40 Gabori's most popular source of income after the fall of the communist regime was paddling and selling second hand goods, brought in bulk from abroad. Immediately after 1989, Gabori started travelling to Hungary, due to obvious linguistic reasons; in the 1990s, Turkey became a very popular destination. After the conflicts in the Balkans, they reoriented towards certain regions of Serbia, Croatia and Slovenia, then to Slovakia and Austria. In the last few years, Gabori tried their luck in France, Poland, Germany, Belgium, the Netherlands, Albania, Macedonia, Greece and Russia (ibidem, p. 44). For more on the transnational migration and trade strategies of the Gabori Roma, see: G. Troc, Transnational Migration and Roma Self-Identity: Two Case Studies, „Studia UBB Sociologia”, 2012, vol. 57, no 2, p. 86-95.

${ }^{41}$ More about the Gabori from Pančevo in: A. Sorescu-Marinković, Gabori Roma in Serbia: the soundscape of an Adventist church, paper presented at the 2016 Annual Meeting of Gypsy Lore Society and Conference on Romani Studies, Centre for Baltic and East European Studies, Södertörn University, Stockholm. 
decades. The relatively lower cost of living in the Serbian capital, higher earnings and other benefits offered by multinational companies make Belgrade attractive for Romanian expats, too.

\section{OTHER}

In the last ten years, a peculiar phenomenon was registered by the Serbian massmedia: Romanian citizens from the Western part of Romania started buying houses in the Serbian villages close to the border with Romania. Romanians did not move to Serbia, but started practicing what could be called weekend or vacation tourism. In 2009 , for example, a quarter of the houses from the village Novi Sip, near Kladovo, in Eastern Serbia, were bought by Romanians. These houses were sold by people working abroad, who did not plan to come back or by those who wanted to move to urban areas. The relatively low prices, the vicinity of Romania and the nice view are very attractive for Romanians. Serbian mass media explained, however, that the reason behind this phenomenon is not political, namely the feared Romanization of the area, but rather economic ${ }^{42}$. In Vojvodina things are similar: Romanian pensioners from Timişoara or Jimbolia buy houses here, as they are much cheaper than in Romania. Headlines like Romanians are buying the village are tempered by the content that explains that, in fact, this is a normal phenomenon which will probably cease once Serbia enters the European Union ${ }^{43}$.

\section{INSTEAD OF CONCLUSIONS}

As we have seen, the reverse ethnic migrations of Romanians to Serbia have been very intense, dynamic and varied in the contemporary period. Vojvodina is the only region with a history of planned or state supported movements of Romanian citizens, however Eastern Serbia has also hosted large numbers of Romanians both in the past and in the more recent periods. The contacts between the two countries in terms of population movements have always been strong. However, the historical contexts and political circumstances have been permanently shaping and affecting the population ethnic profile and transborder movements.

Nevertheless, for a better understanding of the migration patterns and tendencies of this region, one should also take a look at the ethnic migrations of Romanians from Serbia towards Romania, in the same period. As the last decade saw a drastic

\footnotetext{
42 Rumuni kupuju kuće u Srbiji, „Politika”, January 6, 2009 - (http://www.politika.rs/sr/clanak/69877/ Drustvo/Rumuni-kupuju-kuce-u-Srbiji [accessed June 23, 2016].

43 Rumuni kupuju selo, „Kurir”, March 20, 2009 (http://www.kurir.rs/komentari/rumuni-kupuju-se lo-clanak-18200 - [accessed November 15, 2015].
} 
decrease of newcomers from Romania, which coincided with Romania being granted membership of the European Union, the opposite phenomenon became ever more emphasized: many Romanian ethnics from Serbia are today studying and living in Romania.

Last but not least, the picture cannot be complete without insight into the transborder movements of the Serbs in these regions, which were not less dynamic, and researchers should focus their attention in the future on this promising topic.

\section{ACKNOWLEDGEMENTS}

This paper stems from the project Contemporary Romanian labour migration to Serbia - towards a new paradigm of Diaspora, which was supported by the ERSTE Foundation Fellowship for Social Research 2015/2016. It is also the result of my longterm involvement in the project Language, Folklore, Migrations in the Balkans (no. 178010) of the Institute for Balkan Studies, funded by the Ministry of Education and Science of the Republic of Serbia.

\section{REFERENCES}

Berta Péter, Intermediate trade, migration, and the politics of ethnicity. Economic strategies among Romanian Gabor Roma, „Acta Ethnographica Hungarica”, 2014, vol. 59, no 1, p. $43-67$.

Brubaker Roger, Ethnicity without Groups, Cambridge 2004.

Cook-Martín David, Viladrich Anahí, The Problem with Similarity: Ethnic-Affinity Migrants in Spain, „Journal of Ethnic and Migration Studies”, 2009, vol. 35, no 1, p. 151-170.

Constante Constantin, Românii din valea Timocului şi a Moravei, Bucureşti 1929.

Constante Constantin, Golopenţia Anton, Românii din Timoc, Bucureşti 1943, vol. 1-3.

Culic Irina, Anghel Remus Gabriel, Ethnicity in Migration. Romanian Immigrants at Home and Abroad, „Studia UBB Sociologia”, 2012, vol. 57, no 2, p. 3-8.

Diminescu Dana, Exerciţiul dificil al liberei circulaţii: o introducere în istoria migrației recente a românilor, in: Sociologia migraţiei: Teorii şi studii de caz româneşti, eds. István Horváth, Remus Gabriel Anghel, Iaşi 2009, p. 45-62.

Dimitrijevic-Rufu Dejan, Rites de passage, identité ethnique, identité nationale - Le cas d'une communauté roumaine de Serbie, „Terrain”, 1994, no 22, 1994, p. 119-134.

Favell Adrian, The New Face of East-West Migration in Europe, „Journal of Ethnic and Migration Studies", 2008, vol. 34, no 5, p. 701-716.

Flora Radu, Rumunski banatski govori u svetlu lingvističke geografije, Beograd 1969.

Gordon Milton, Assimilation in American Life, New York 1964.

Huţanu Monica, Sorescu-Marinković Annemarie, ,For us, it's not a matter of research, but a matter of life": language ideologies in the standardization of Vlach in Serbia, paper presented at the conference Communication in the „, Country of Babel”. Language Ideological Debates on Contact Varieties, 11th and 12th November 2015, University of Bern (in print).

Huţanu Monica, Sorescu-Marinković Annemarie, Graiul vlah în şcolile din Serbia răsăriteană: provocări şi perspective, „Philologica Jassyensia”, 2015, vol. 11, no 2, p. 201-211. 
Iordachi Constantin, Politics of citizenship in post-communist Romania: Legal traditions, restitution of nationality and multiple memberships, in: Citizenship Policies in the New Europe, eds. Rainer Bauböck, Bernhard Perchinig, Wiebke Sievers, Amsterdam 2009, p.177-210.

Joppke Christian, Selecting by Origin. Ethnic Migration in the Liberal State, Cambridge 2005.

Jovanović Nadica, Gramatika vlaškog jezika, Negotin 2013.

Măran Mircea, Românii din Voivodina - istorie, demografie, identitate românească în localităţile Voivodinei, Zrenjanin 2009.

Măran Mircea, Românii din Banatul sârbesc în anii interbelici (1918-1941), Cluj-Napoca 2012.

Meteş Ştefan, Emigrări româneşti din Transilvania în secolele XIII-XX, Bucureşti 1977.

Mioc Eugen, Comunismul în Banat (1944-1965). Dinamica structurilor de putere în Timişoara şi zonele adiacente, Timişoara 2010, vol. 2.

Neiescu Petru, Beltechi Eugen, Mocanu Nicolae, Atlas Lingvistic al Regiunii Valea Timocului. Contribuţii la atlasul lingvistic al graiurilor româneşti dintre Morava, Dunăre şi Timoc, Reşiţa 2006.

Nistor Ionuţ, ,Procesul titoismului” în România (1950). Documente, Iaşi 2015.

Popi Gligor, Românii din Banatul Sârbesc, Pančevo 1993.

Popi Gligor, Rumuni u jugoslovenskom Banatu između dva rata: 1918-1941, Novi Sad 1976.

Sandu Dumitru, Migraţia transnaţională a românilor din perspectiva unui recensământ comunitar, „Sociologie românească", 2000, vol. 3-4, p. 5-52.

Schierup Carl-Ulrik, Will they still be dancing? Integration and ethnic transformation among Yugoslav immigrants in Scandinavia, Umeå 1986.

Sikimić Biljana (ed.), Banjaši na Balkanu. Identitet etničke zajednice, Beograd 2005.

Sikimić Biljana, Romanians in Serbian Banat: Dynamic Epistemology, in: The Multilingual Society Vojvodina. Intersecting Borders, Cultures and Identities, eds. Tomasz Kamusella, Motoki Nomachi, Sapporo 2014, p. 51-73.

Sorescu-Marinković Annemarie, Romanian female migration to northeast Serbia, in: Migration and Identity: Historical, Cultural and Linguistic Dimensions of Mobility in the Balkans, ed. Petko Hristov, Sofia 2012, p. 217-231.

Sorescu-Marinković Annemarie, Românii din Timoc astăzi. Ființe mitologice, Cluj-Napoca 2012.

Sorescu-Marinković Annemarie, Foggy diaspora: Romanian Women in Eastern Serbia, „Studia UBB Sociologia", 2016, vol. 61, no 1, p. 37-57.

Steiner Johann, Magheţi Doina, Mormintele tac. Relatări de la cea mai sângeroasă graniţă a Europei, Iaşi 2009.

Trandafoiu Ruxandra, Diaspora Online. Identity Politics and Romanian Migrants, Oxford 2013.

Troc Gabriel, Transnational Migration and Roma Self-Identity: Two Case Studies, „Studia UBB Sociologia", 2012, vol. 57, no 2, p. 77-100.

Ţîrcomnicu Emil, Identitate românească sud-dunăreană. Aromânii din Dobrogea: sărbători, obiceiuri, credinţe, cultură şi viaţă comunitară, Bucureşti 2004.

Wallace Claire, Stola Dariusz (eds.), Patterns of Migration in Central Europe, Basingstoke 2001. 
